\title{
Analysis of the Impact of COVID-19 on Macao's Economy
}

\author{
Shulei Huang ${ }^{1, *}$ \\ ${ }^{1}$ School of Economics, Shandong University of Finance and Economics, Jinan, Shandong 250000, China \\ *Corresponding author. Email: huanghsl@outlook.com
}

\begin{abstract}
The COVID-19 epidemic is raging around the world, and without exception, Macao has also been affected. Macao's economy was down due to the pandemic. This paper through the analysis of official data and policy discussion analyses the impact of the pandemic on Macao's economy. The pandemic has indeed had negative impacts on Macao's economy, especially its pillar industries, gambling and tourism. Nonetheless, measures of the Macao SAR Government were valid for economic recovery and future development of economy. The government's financial support and the adjustment of taxation have reduced the pressure on people and enterprise.
\end{abstract}

Keywords: COVID-19, Macao, Economy, Gambling, Tourism.

\section{INTRODUCTION}

COVID-19 spread rapidly in China at the end of 2019 and early 2020. 31 provinces, municipalities and autonomous regions had launched a level-one response to major public health emergency. Macao is a Special Administrative Region of the People's Republic of China, located on the southeast coast of the Chinese mainland, adjacent to Zhuhai City, Guangdong Province, with a total land area of 32.9 square kilometers[1]. Macao with Hong Kong and Guangdong province form the Guangdong-Hong Kong-Macao Greater Bay Area, and it is an important node for the marine Silk Road[2]. Hence, Macao is not only valuable to China, but also to the world. In early January 2020, after getting the news of the pandemic, the Macao Special Administrative Region Government promptly responded to control the pandemic within a controllable scope[3]. Because of the single industry, Macao's economy is dependent on gambling and tourism. The damage to these two industries has had an impact on residents and enterprises. So the Macao government has implemented several measures to deal with the pandemic and provided benefits and assistance to residents and enterprises. Based on the analysis of official data, this paper analyses the impact of the pandemic on Macao's gambling industry and tourism. Also, the measures during the pandemic and the policies for economic development put forward by the SAR government would also be discussed. Macao's practical experience can provide some reference for the epidemic prevention and control work in other cities.

\section{OVERVIEW}

The aging population in Macao is serious. The international standard for a country to enter an aging society is that the proportion of people over 65 years old in the total population reaches $7 \%$. In 2020 , the population over the age of 65 will account for $12.9 \%$ of the total population of Macao, which is higher than the normal standard of $7 \%[1]$. Older people are susceptible to infection[4] and the ageing of the population could lead to a decline in the supply of labour[5]. Furthermore, Statistics in 2019 show that Macao's secondary industry accounted for $4.3 \%$ and the tertiary industry accounted for $95.7 \%$. Most of the tertiary industry is the convention and exhibition industry, gaming industry and tourism-related industries[1]. This leads to a single economic structure in Macao. So economy of Macao is extremely vulnerable. In this way the pandemic has not only had a huge impact on the people's livelihood and economy in mainland China, but also posed a great threat to economy in Macao. Unemployment rate in Macao started rising in the first quarter of 2020, and although it declined 
in the fourth quarter, it was still significantly higher than in 2019. Affected by the epidemic, the yearon-year change in Macao's real GDP has dropped significantly. GDP per capita in 2020 is MOP 285,314, which is the lowest since 2009[1]. The impact was greatest in the gambling industry and tourism, which are important pillars of Macao's economy. The economic structure of Macao is very simple. Gaming taxes account for the vast majority of government revenue. Tourism, retail, hotels and other industries are mostly derivatives of the gambling industry[2]. In 2020, the entertainment, culture, gaming and other service industries in Macao accounted for $23.1 \%$ of the total employment population in Macao, of which gaming and intermediary activities accounted for $20.5 \%$. Employment in the hotel, restaurants and similar activities industry accounted for $13.8 \%$ of the total employment, second only after gaming and junket activities[1].

\section{ANALYSIS OF THE IMPACT OF COVID-19 ON MACAO'S ECONOMY}

\subsection{The Impact on the Gaming Industry}

The gambling industry, which in Macao has a long history, is important in Macao's economy. This is the unique feature of Macao's economy[6]. Therefore, in the study of Macao's economy, the gambling industry is the first to be referred.

On the contrary, the gambling industry suffered a significant loss during the pandemic period. The gambling industry and related entertainment businesses in Macao were suspended on February 5, 2020, and on February 20, 2020, twenty nine casinos reopened[7]. The biggest sector of Macao's gaming industry is Games of Fortune. According to the statistics, Gross revenue from Games of fortune was 30,486 million MOP in the first quarter of 2020[6], down $60 \%$ from 76,152 million MOP in the first quarter of 2019. The gross revenue from Games of fortune reached its lowest level in the second quarter of 2020, and it was 3234 million MOP merely[6]. That was a $96 \%$ drop from the same period in 2019. Gross revenue gradually recovered in the third quarter and fourth quarter, but the rate of change remained negative compared to the same period in 2019[13], decreased by $93 \%$ and $70 \%$ respectively. Total gross revenue from Games of fortune was 60,441 million MOP in 2020, while in 2019 it was 292,455[6], it declined significantly by approximately $79 \%$ over the last years.

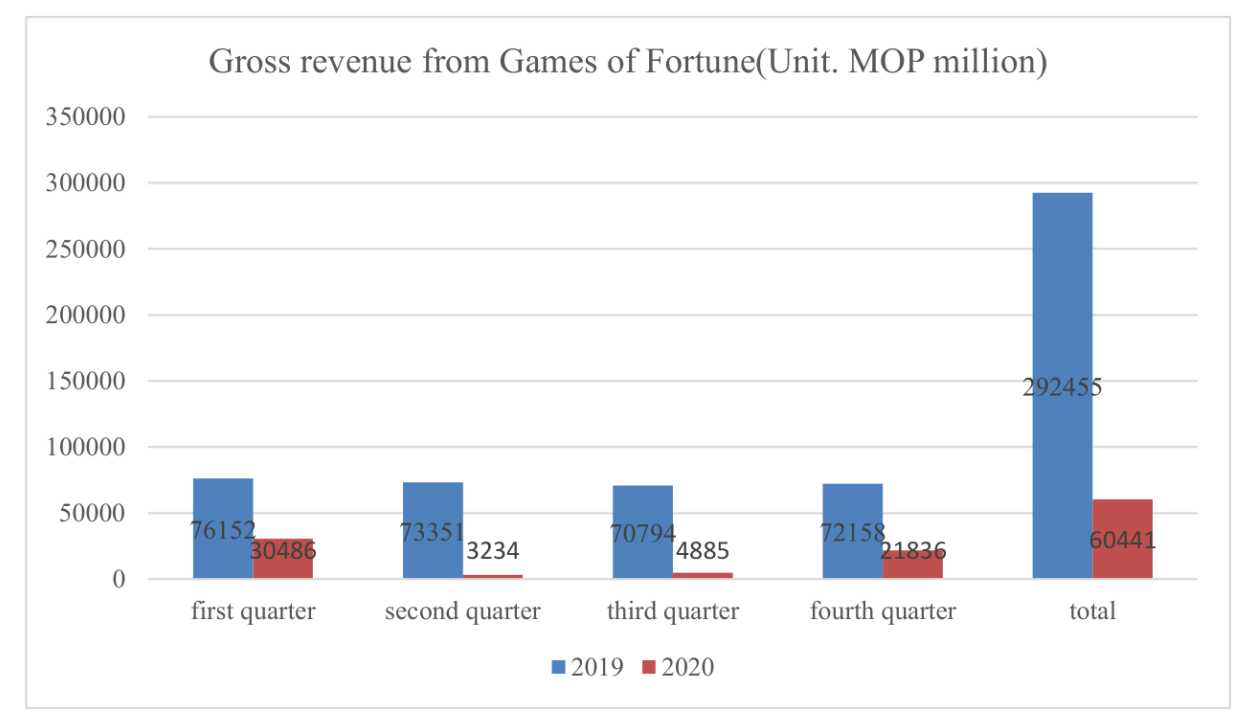

Figure 1 Gross revenue from Games of Fortune. 


\subsection{The Impact on the Tourism}

The mainland China suspended tourist visas to Hong Kong and Macao from January 29, 2020[8], resulting in a sharp drop in the number of arrivals to Macao in 2020. The total number of tourists in Macao in 2020 is about 5.9 million, compared with 39.4 million in 2019, a year-on-year decrease of $85 \%$. Visitors from Mainland China, which the most segment and that occupied more than $80 \%$, was 4.75 million[1]. This data is down about $83 \%$ from 2019. Both overnight visitors and same-day visitors dropped by approximately $85 \%$. Total spending of visitors (excluding gaming expenses) declined $81.4 \%$ in 2020, though per-capita spending of visitors rose. Fewer tourists also impact restaurants. Persons engaged of restaurants decreased by $5.7 \%$, average earnings in restaurants area went down $7.4 \%$ as well[1].

\subsection{Analysis of Declining Tourists in Gaming and Tourism}

The pandemic has had a very negative impact on the gaming and tourism industries. As a result of the prevention and control measures, the number of guests in the gaming and tourism industries has decreased significantly, which is one of the important reasons for the huge loss of revenue in these two industries. The development of these two industries depends on the passenger flow. If passenger flow decreases, the income of the people who engaged in these industries would decline, and this leads to unemployment of people who are employed here. Furthermore, the growth of unemployment may cause social unrest and increased crime. Therefore, in order to avoid hindering social development, the SAR government must take countermeasures.

\section{MEASURES OF THE MACAO SAR GOVERNMENT}

Gaming industry and tourism-related industries, such as restaurant, shopping, retail trade and so on, are the pillar industries in Macao. Most residents are engaged in these two industries. The impact of the pandemic on the gaming industry and tourism is bound to have an economic impact on residents and some businesses. In order to solve this problem, the government has taken a number of measures.

\subsection{Financial Aid}

Financial aid included aid to individuals and aid to enterprises. In terms of individual assistance, first of all, receiving financial assistance families received an additional full subsidy in March 2020, in addition to the daily subsidy. Secondly, for all Macao residents, the government paid out the cash share from July to September in advance in April 2020. Besides, the government has formulated a preferential plan for electronic consumption to issue consumer cards to residents who can consume in areas specified by the government. Moreover, the government also provided concessionary or even free water and electricity for residential users. In terms of business assistance, the Government has implemented a rent reduction scheme. Government property, such as shopping centres and kiosks, were waived for all rents from February to April. The government also formulated auxiliary measures for small and medium-sized enterprises, which could also apply for interest subsidies on bank loans to small and medium-sized enterprises. The government also subsidized water and electricity bills[3][9].

The issuance of consumer cards helped boost domestic demand and revive the economy. The exemption of utility bills has reduced the financial pressure of residents who have been living at home for a long time due to the epidemic. However, residents do not need to pay water and electricity bills themselves, which may lead to a waste of resources.

\subsection{Tax Adjustment}

The tax adjustment included tax reduction and duty free measures. The tax cuts included an increase in the 2019 occupational tax rebate to $70 \%$, with maximum limit of 20 thousand and deducted the supplementary tax on income payable in 2019. The proportion of employment tax exemption increased to $30 \%$ in 2020 . Furthermore, it also deducted the housing tax for commercial and industrial use. As regards the duty free, the administrative licensing fee, stamp duty and vehicle licence tax for 2020 was waived or refunded. In addition, the 5\% tourism tax on the designated sites was also waived for six months. The housing tax also was waived for residential homes in 2020[3].

The exemption and reduction of taxes will help reduce the burden on enterprises and increase their vitality. In the context of the pandemic, it is conducive to the operation of enterprises. It also 
guarantees the livelihood of the residents. But such a change in taxes would reduce government revenues.

\section{PUBLIC POLICY AFTER THE PANDEMIC}

The pandemic caused a heavy blow to Macao's economy. The number of tourists to Macao has decreased significantly, and Macao locals have also minimized their entertainment time. This had a negative impact on the people-dependent gaming and tourism industries. As a result, Macao's economic income declined. In the context of Macao's economic downturn, Macao should not only promote appropriate economic diversification, but also strengthen cooperation with other cities in the Greater Bay Area.

\subsection{Promoting Economic Diversification}

The policy address proposed to promote economic diversification in Macao includes the following contents. Above all, industrial development should be re-positioned. Secondly, SAR government should expedite development of a modern financial services industry and establish a bond market. And then, traditional Chinese medicine should be industrialized[10]. The only state key laboratory established in Macao in the year 2011 and WHO Collaborating Centres for Traditional Medicine was founded in Macao in the year 2015[11][12]. These are favorable conditions for the development of the traditional Chinese medicine industry in Macao.

As for the modern financial services industry, although green bonds were issued in Macao, but issuers were not Macao Entity Enterprises. Therefore, Macao could also start from green bonds to promote the development of special financial industries, including green finance[12][13].

When cross-boundary e-commerce matures, then people in other countries and people in Chinese mainland can buy Macao's commodities and souvenirs online. In this way, even if people cannot go to Macao due to policies or other reasons, they can also bring income to Macao and promote the development of the transportation industry.

\subsection{Enhancing Cooperation with Other Cities in the Greater Bay Area}

In the year 2019, "Outline Development Plan for the Guangdong-Hong Kong-Macao Greater Bay
Area" issued by CPC Central Committee and State Council of the People's Republic of China. The Guangdong-Hong Kong-Macao Greater Bay Area consists of multiple cities in three regions (Hong Kong, Macau and Guangdong Province). This area is one of the most active areas in China's economic activities. Macao can rely on its regional advantages and play its unique role to further develop into a world tourism and leisure center. In addition, Macau can also serve as a bridge between mainland China and Portuguese-speaking countries, strengthening economic and cultural exchanges between each other. The strengthened cooperation between Macao and the Mainland will provide more development opportunities for Macao residents. This is conducive to the long-term stability of Macau's economy[14].

\section{CONCLUSION}

This article confirmed that the pandemic indeed had a negative impact on Macao's economy, especially on the gaming and tourism industry. The SAR government adopted measures such as financial aid and tax adjustment to ensure economy and the people's livelihood. Furthermore, for the long-term development of Macau's economy, Macau needs to diversify its development and strengthen cooperation with Hong Kong and some cities in the Mainland.

Because of the human-to-human transmission of COVID-19, the gaming industry still needed to avoid gathering and reduce the number of people in public places. As a result, the gambling industry has fewer consumers, resulting in lower revenues. Then the global outbreak, coupled with strict controls in mainland China, sharply reduced the number of visitors to Macao. This has also had an impact on tourism, including hotels and restaurants and so on. To minimize the damage to enterprises and households from falling incomes, the SAR government adjusted taxes plus provided financial aid. These measures released their economic pressure, making the lives of residents and also production and operation of enterprises less affected from the pandemic. Some of Macao's economic shortcomings have been emerged by the pandemic. For the better development of Macao's economy, the SAR government decided to promote economic diversification and enhancing cooperation with other cities in the Greater Bay Area.

Macao has other industries, such as manufacturing, retail trade and MICE and so on. 
These were all influenced by COVID-19. However, due to the limited time, space and ability of the author, this essay is not mentioned. For instance, MICE is held every year in Macau, but due to the impact of the 2020 epidemic on Macau's economy, most exhibitions have been cancelled or postponed. In future research, these industries could be studied.

\section{AUTHORS' CONTRIBUTIONS}

This paper is independently completed by Shulei Huang.

\section{REFERENCES}

[1] Government of Macao Special Administrative Region Statistics and Census Service. https://www.dsec.gov.mo/en-US/. 2021.6.21

[2] Bai Yanfeng, Li Yongxi. Macao COVID-19 epidemic response mechanism and financial implications of emergency response [J]. Sub National Fiscal Research, 2020(04):26-35.

[3] Macao SAR Government Portal. https://www.gov.mo/en/. 2021.6.21

[4] Tang Qijing. The COVID-19 Pandemic has Raised the Alarm of Population Aging in China Ahead of Time [J]. Scientific Research on Aging, 2020,8(05):54-63.

[5] Feng Jianfeng, Chen Weimin, Shao Zhouzhou. Study on the potential risk of population age structure change to economic growth in China [J/OL]. Statistics \& Decision, 2021(12):122126

[6] Gaming Inspection and Coordination Bureau Macao SAR. http://www.dicj.gov.mo/web/en/frontpage/ind ex.html. 2021.6.23

[7] Government Information Bureau of the Macao SAR. https://www.gcs.gov.mo/home/en?2. 2021.6.26

[8] Ma Yingtong. Visits to and from Macao fell by more than $60 \%$ in 2020 compared with the same period last year [J]. China Conference \& Exhibitiion, 2021(02):46.

[9] The Macao SAR Government launched economy and people's livelihood support measures to respond to pandemic. http://www.xinhuanet.com/politics/202001/31/c_1125516952.htm. 2020.1.31/2021.6.24
[10] The Government of the Macao Special Administrative Region Policy Address for the Fiscal Year 2021. https://www.policyaddress.gov.mo/index.html ?1=en. 2021.6.28

[11] Wang Lingxi. Traditional Chinese Medicine Industry: Macao's New Growth Pole [J]. China Today, 2020,69(02):62-63.

[12] Sheng Li. Macao's Economic Development after the Return: Achievements, Experience and Prospects [J]. People's Tribune, 2020(01):58-63.

[13] People's Tribune, 2020(01):58-63. Shang Jin. Promote the Development of "Substantial Green" Bonds in the Guangdong-Hong KongMacao Greater Bay Area [J]. China Bood, 2021(03):41-45.

[14] The State Council of the CPC Central Committee issued the "Outline Development Plan for the Guangdong-Hong Kong-Macao Greater Bay Area". http://www.xinhuanet.com/politics/201902/18/c_1124131474.htm. 2019.2.18/2021.6.25 